Partnership under pressure

A process perspective on decentralized bargaining in Danish and Australian manufacturing

Ilsøe, Anna; Pekarek, Andreas; Fells, Ray

Published in:

European Journal of Industrial Relations

DOI:

$10.1177 / 0959680117708375$

Publication date:

2018

Document version

Peer reviewed version

Citation for published version (APA):

Ilsøe, A., Pekarek, A., \& Fells, R. (2018). Partnership under pressure: A process perspective on decentralized bargaining in Danish and Australian manufacturing. European Journal of Industrial Relations, 24(1), 55-71. https://doi.org/10.1177/0959680117708375 


\title{
Partnership under pressure: A process perspective on decentralized bargaining in Danish and Australian manufacturing
}

\author{
Anna Ilsøe \\ Københavns Universitet, Denmark \\ Andreas Pekarek \\ University of Melbourne, Australia \\ Ray Fells \\ University of Western Australia
}

Corresponding author:

Anna Ilsøe, Sociologisk Institut, Københavns Universitet, Øster Farimagsgade 5, Postboks 2099, 1014 København K, Denmark

Email: ai@faos.dk

\begin{abstract}
Decentralization of collective bargaining has become widespread in developed economies, and EU policies have pushed this trend further. We use process-tracing methodology to explore the consequences of decentralization for the reproduction of partnership bargaining relations at company level. We compare two cases of decentralized bargaining in manufacturing, one in Denmark and one in Australia. Agreement-based decentralization seems to offer better process conditions for reproduction of local partnership compared to decentralization regulated by law. This implies that future decentralization measures should be negotiated rather than imposed.
\end{abstract}

\section{Keywords}

Partnership, decentralized bargaining, process tracing, manufacturing, Denmark, Australia

\section{Introduction}

The decentralization of collective bargaining has been a major trend in many developed economies over recent decades, placing the onus on the local parties to negotiate agreements. The nature of these single-employer negotiations can range from adversarial to collusive (Walton and McKersie, 1965). Although the public policy preference across Europe is for workplace dialogue and collaboration (European Commission, 2015), not all such 'partnerships' live up to the promise of mutuality (Bacon and Blyton, 2007; Oxenbridge and Brown, 2004).

A key element in any partnership is how the parties interact, but the processes through which ostensible 'partners' negotiate have been under-examined. We draw on negotiation theory and use process-tracing methodology to examine two local management-union negotiations, one in Denmark and the other in Australia. Both negotiations occurred in the context of a workplace partnership but against different institutional backdrops. In both countries, bargaining decentralization has assumed great importance since the 1980s; however this shift has been legally regulated in Australia but is far more voluntarist in Denmark. Our cases suggest that these different approaches to decentralization have important implications for the negotiation process and, by extension, for the sustainability of partnerships at company level.

We first introduce the major European debates on bargaining decentralization before contrasting the Danish and Australian frameworks. We then draw on negotiation literature to develop an analytical framework. After describing our research methods, we present the two cases, followed by a comparative analysis and conclusion. 


\section{Collective bargaining decentralization: European debates}

The decentralization of collective bargaining in Europe is well documented (Schulten, 2005; Traxler, 1995). The EU has pushed member states, particularly in Southern Europe, to decentralize further the processes for setting pay and working conditions since the 2008 financial crisis, to encourage workplace flexibility and job growth (Bechter and Brandl, 2015; Keune, 2015). This has resulted in increasing legislative or regulatory control over both the process of agreement-making and the substantive outcomes (Voss et al., 2015). This legislative approach contrasts with the more agreement-based framework for change typical of the Nordic countries (Campos Lima and Jørgensen, 2016)

Decentralization of national industrial relations systems involves a shift towards singleemployer bargaining, but this can also take place within a broader sectoral or national framework. Traxler (1995) highlighted the difference between 'organized decentralization' covered by sectoral framework agreements and union involvement, and 'disorganized decentralization'. More recent studies find variety in how organized decentralization is achieved and maintained, through agreement or through legislation, and call for differentiation between more and less articulated forms of decentralization (Campos Lima and Jørgensen, 2016; Visser, 2016).

In this respect, comparing Australia and Denmark is instructive. In Denmark, managementunion negotiations occur in the context of a well-established voluntary social partnership whereas in Australia, similar negotiations occur in a legalistic framework. Both have experienced shifts towards decentralization, and so Australian experience offers a point of comparison with recent trends in Europe.

Whatever the form of decentralization, the local parties assume greater responsibility for negotiating pay, hours and other conditions. However, there is debate over whether decentralization favours employers or permits mutual employer-employee benefits (Baccaro and Howell, 2011; Marginson, 2015). Even in the case of articulated decentralization, questions remain how far it extends the scope of collective bargaining to less regulated but growing sectors or whether statutory minimum wages are needed to provide a safety net (Amlinger et al., 2016). In Norway, for example, collective agreements have been statutorily extended to cover some private services (Andersen et al., 2014). Denmark has no statutory mechanisms to secure minimum wage levels, reflecting concerns that these would undermine the voluntarist model of labour market regulation (Dølvik, 2016; Schulten, 2016).

One of the reasons for bargaining decentralization is that new forms of work organization require more flexible employment conditions (Katz, 1993). Yet can decentralized bargaining withstand continued demands from employers and governments for greater workplace flexibility? If the realistic scenario is for the continued decay of industrial relations systems, including decentralized ones (Hyman, 2015), then employer unilateralism or legislative minima, rather than negotiation between the parties, will determine employee terms and conditions. In the face of such challenges, the way in which management-union negotiations are conducted becomes an important element in shaping the sustainability of decentralized bargaining.

\section{Variations in decentralization: Danish and Australian manufacturing}

The European debate on decentralization and its consequences is the backdrop to our comparison of decentralized bargaining in Denmark and Australia. Both systems were established in response to industrial conflict during the 1890s. The Australians opted for an arbitral framework of dispute resolution through legislation in 1904(Hamilton, 2011). The currently-named Fair Work Commission (FWC) has a range of regulatory responsibilities including adjusting minimum wages, approving enterprise agreements, maintaining modern awards and resolving disputes. The Danes initiated a voluntaristic approach through the 1899 'September Compromise' (Septemberforlig), negotiated between the employer and union confederations (Due et al., 1994). These core characteristics have prevailed and have accommodated shifts towards decentralization in both countries, primarily towards 
the end of the last century. Each system is described briefly while key points of comparison concerning decentralized bargaining in manufacturing are summarized in Table 1.

[Table 1 about here]

\section{Decentralization of collective bargaining in Danish manufacturing}

The Danish labour market is mainly regulated by agreements negotiated between unions and employers' organizations at sectoral level; legislation plays a very limited role. Nearly 70 percent of employees are unionized, and a similar proportion are covered by sectoral agreements (Due et al., 2010). Within the framework of these agreements, bargaining competencies have been delegated to workplace level. The 'Industrial Agreement' (Industriens Overenskomst) in manufacturing has set the trend.

For many years, manufacturing made up more than half of Danish exports; but the sector has been shrinking over recent decades. Today, manufacturing creates 16 percent of GDP and employs 16 percent of the labour force (Danmarks Statistik, 2013). The sector has a long history of decentralized bargaining (Due et al., 1994). As early as 1902, metal industry pay became a matter of company-level bargaining, and over the past century this tradition of local wage-setting spread to the rest of manufacturing. At present, only minimum wages (which make up approximately half the total wage) are negotiated at sector level in manufacturing, with actual wage increases negotiated annually at company level. During the 1990s, possibilities for company-level bargaining were expanded to include working hours, and from 2000 the local agenda could be further expanded subject to local consent (Navrbjerg et al., 2001). More than 80 percent of companies covered by the Overenskomst have negotiated company-level agreements on both wages and working hours (Ilsøe, 2012).

A key feature of the system is that either party has the right to terminate unilaterally any local agreement by giving two months' notice, in which case the employment conditions revert back to those in the sectoral agreement negotiated by Dansk Industri (DI, Confederation of Danish Industry) and CO-Industri (Central Organisation of Industrial Employees). This right of veto was an important precondition for unions to accept the delegation of bargaining competencies to the company level. Similarly, the workplace bargaining authority of shop stewards (tillidsreprasentanterne) is formally recognized in the Overenskomst. There is no provision for legal industrial action during companylevel bargaining; wildcat strikes occur but have been decreasing over the last two decades (Ilsøe, 2009). Shop stewards are elected among union members at the workplace and enjoy exclusive bargaining rights; more than 70 percent of companies covered by the Overenskomst have at least one shop steward present (Ilsøe, 2012).

\section{Decentralization of collective bargaining in Australian manufacturing}

Historically, Australia had an arbitral model of industrial relations where tribunals resolved collective disputes by conciliation or arbitration, giving rise to a complex system of enforceable industry or occupational 'awards'. Collective bargaining was a secondary process for much of the 20th century (Gahan and Pekarek, 2012). However, from the 1980s legislative change and new wage-setting principles overseen by the tribunal paved the way for predominantly decentralized bargaining, and this is now the primary mechanism through which pay and conditions of employment are determined (ABS, 2015a). Industrial relations are highly regulated, principally through the Fair Work Act 2009, administered by the FWC. The legislation gives priority to enterprise bargaining, and imposes both procedural and substantive requirements on the bargaining parties. Union officials typically lead the enterprise negotiations but do not enjoy exclusive bargaining rights: non-union employee representatives can participate. Unlike in Denmark, shop stewards are not formally recognized but act as part of the union negotiating team. Union membership has long been in decline, with density down from approximately 40 percent in 1990 to about 15 percent in 2014 (ABS, 2015b).

As in Denmark, there is a combination of sectoral regulation and enterprise arrangements. 122 'modern awards' (periodically reviewed by the FWC) set out minimum pay and conditions for each 
industry and underpin any enterprise agreement. The tribunal may only approve an agreement if it leaves employees better off overall than if they remained under the relevant award, it then replaces the award and neither party can unilaterally opt out of it during its term (up to 4 years).

Historically, the manufacturing industry has been of major significance for Australian industrial relations. In particular, the metal industry award set the benchmark of industrial standards, and the metal workers' union (now the Australian Manufacturing Workers' Union) was one of the largest, powerful and militant in the country (Thornthwaite and Sheldon, 1996). However, as in other developed economies, the industry has declined in significance, both in terms of employment (7 percent) (ABS, 2015a) and as a share of GDP (6 percent) (ABS, 2015c).

\section{Developing and maintaining cooperative bargaining relations}

The viability of decentralized collective bargaining rests on the capacity of employers and unions to produce mutually beneficial outcomes for the parties. Walton and McKersie (1965) analysed collective bargaining as a process through which the parties defined the terms of their interdependence, with their relationship ranging from conflict to collusion. Later, when American management was seeking to reshape industrial relations in the face of competitive pressures, Walton et al. (1994) argued that management could force a change in their management-union and employeremployee relationships; they could foster a change; or could attempt to escape from having a relationship with a union altogether. Similar pressures provide the context for government policies to devolve bargaining to the workplace. To be successful over the longer term, any bargaining requires stability of relationships and mutually beneficial outcomes. The evidence in support of genuine and sustained mutual gain or partnership is patchy (Fells and Prowse, 2016). We now explain how we analyse the bargaining process and how it affects the reproduction of bargaining relationships.

\section{Dimensions of the negotiation process}

Workplace negotiations involve complex interaction dynamics between the negotiators (Bacon and Blyton, 2007; Cutcher-Gershenfeld, 2011). Research suggests that four elements are significant in influencing whether negotiations are adversarial or collaborative: goal alignment, the exercise of power, the level of trust and the extent of information exchange.

How negotiators frame the items for discussion will influence whether they bargain adversarially or integratively. Most negotiators expect bargaining to be zero-sum (Bazerman and Neale, 1992). However, if they have concern for the other party's outcome they are more likely to adopt a collaborative approach (De Dreu et al., 2000). Hence models of mutual gains bargaining emphasise the need for management and union to have a common understanding to encourage mutuality in goal-setting.

How the parties assess and exercise power also shapes negotiations. This has to do with alternatives: how else might a party achieve its goal if agreement cannot be reached? In the workplace the alternatives are the strike or lockout, power being derived from the ability to impose economic costs (Chamberlain and Kuhn, 1965). The parties' perceptions of their relative strength is often based on their assessment of the prevailing economic context; a tight labour market will encourage the union and its members to press harder.

Trust between negotiators may be calculative, or can be built through an identification of common interests or goals (Lewicki and Stevenson, 1997). Where the parties take time to interact and understand each other, there is likely to be greater trust.

Competitiveness or cooperation in negotiations also reflects the extent to which the parties exchange information (Thompson, 1991). A reluctance to share information or a willingness to use it to undermine the other party develops an adversarial dynamic, whereas sharing information, particularly regarding core interests and priorities, increases the likelihood of positive-sum solutions.

We add a fifth dimension, the institutional structure of local negotiations. As we learned from our comparison of decentralization in Danish and Australian manufacturing, the framework for company bargaining can differ substantially. For example, in Denmark, on-site union representatives 
act as chief negotiators, whereas bargaining in Australia is mainly conducted by external officials.

We can present these dimensions of negotiation through characteristics that reflect either stability or fragility of the relationship between management and union (Table 2). This provides a framework for the analysis of our two cases.

[Table 2 about here]

\section{Investigating decentralized bargaining: a process tracing approach}

We use a case study design that examines the negotiation process from the preparations preceding formal negotiations to the approval of the negotiated agreement by employees. We draw on processtracing methodology, which has become widely used within political science (Beach and Pedersen, 2013; Collier, 2011; George and Bennett, 2005). This highlights the processual aspect of causality by combining within case analysis and controlled comparison, focusing on the causal sequences over time linking preconditions with outcomes and drawing attention to the events in between (Tansey, 2007).

Our overall research design is to follow negotiations closely over time and collect data through interviews in the different phases of the negotiations (before, during and after), to examine what differences and similarities can be observed and what might contribute to a reproduction of bargaining relations. Since the Danish and Australian labour markets are differentiated by voluntaristic and legalistic frameworks for bargaining decentralization, we sought to isolate the potential effect of this difference on the reproduction of company-level bargaining relations through a controlled comparison of one bargaining round in two similar companies in Danish and Australian manufacturing.

The main case selection criteria were high levels of trust between the local bargaining parties and long records of mutual gains bargaining outcomes. As a condition of access, we have to maintain the anonymity of the workplaces, which were both medium-sized export-oriented manufacturing plants with a skilled workforce (150 blue-collar workers in DK Productions and 110 in Ozco) and high union density (100 and 80 percent respectively). Both were part of multinational companies.

Information was gathered through separate interviews with the chief negotiators on both sides before, during and after the negotiations; through company visits and observation of negotiating meetings; and through analysis of documents about the company, the union, the employees and relevant agreements. A total of 14 interviews were conducted throughout 2014, eight in the Danish case and six in Australia. Interview guides included questions on the frequency of contact with the other party, the quality of formal and informal contacts, trust, information-sharing, topics discussed, significant incidents, interaction with constituencies, current audiences (top management, workers, unions, community, public sphere) and the quality of negotiations. All interviews were transcribed, coded and analysed. First, we developed a time-line and identified phases in each bargaining process. Second, we identified events that affected the relations between the parties. Third, we compared comments from the chief negotiator on each side to verify findings. We then wrote a case description for each case before comparing findings across the two cases, using our framework on stability and fragility in workplace bargaining relations.

\section{Denmark: Wage negotiations at DK Productions}

Management and shop stewards at DK Productions have negotiated many local agreements on matters ranging from flextime to fringe benefits, and they both describe a high level of trust in their bargaining relationship. Wage negotiations for production workers are conducted annually. The production and HR managers represent the company. The production manager has been with the company for two years, but has 20 years of negotiating experience from other companies.

The shop steward representing the largest group of production workers leads negotiations on the workers' side, assisted by other shop stewards. He has worked at the company for many years and has been a shop steward for two. During the last two years, managers and shop stewards have 
conducted two wage bargaining rounds and negotiated over two possible rounds of redundancies, but while the latter were resolved quickly, the wage bargaining took longer, unusually involving confrontation between the parties.

Six months of formal negotiations in 2013 ended with a wildcat strike and no wage increases, because of disagreement regarding a minority of unskilled workers. Managers perceived wages for this group as too high and sought to moderate their increases, preferring to raise wages for skilled workers to facilitate their recruitment and retention. However, management expected a different result in 2014: 'last year the negotiations ended in a zero solution, which was not intended from our side. We wanted one wage increase for the skilled workers and another one for the unskilled. And the shop stewards said: "if we cannot get it for all, we will not have anything". I expect it to be different this year. I do not expect a zero wage increase for all.'

Since the conflict and deadlock in 2013, management and shop stewards have taken several initiatives to improve relations. For example, they introduced a monthly meeting between production managers, HR managers and shop stewards to exchange information across production units. Shop stewards meet every two weeks with managers in each workshop, and the board of the local union 'club' (branch) meets once a week.

\section{Preparation for the negotiations}

Before the new bargaining round, management and shop stewards informally agreed to discuss the form and content of the forthcoming wage negotiations at an off-site workshop in January 2014. Shop stewards also presented management with a proposal for distributing wage increases between skilled and unskilled workers. However, before the planned workshop could proceed a deterioration in business conditions raised the prospect of redundancies. The parties managed to negotiate a solution avoiding lay-offs and then held the planned workshop.

In late January, the HR manager contacted the leading shop steward proposing that the wage negotiations be held as a two-day session. The shop steward referred to these preparatory interactions as the most important phase of the 2014 negotiations: 'I like to talk with management before we sit down at the bargaining table. Then both of us know the bargaining goals of the other side.... I prefer to do most of the negotiations in the hallway before we sit at the table. In reality, a large part of the negotiations takes place before sitting down.' Both the manager and the shop steward underline that these preliminary meetings were important, allowing them to exchange views informally. Furthermore, this approach allowed them to address potential disagreements within their bargaining team or among their constituencies before the formal bargaining process.

In February, the shop stewards collected data on wages through their networks in other production units of the company in Denmark. In mid-March, the union club organized an extraordinary meeting on wage negotiations, attended by about 80 production workers. Two days later, management and shop stewards held a formal meeting and agreed to hold the negotiations as a two-day off-site workshop. The smaller than usual management team would comprise a production manager, the HR manager and an assistant, while three shop stewards would represent workers as in 2013. In mid-March, management participated in a Dansk Industri conference on wage bargaining and gathered information from other companies.

\section{The negotiations and agreement}

At the outset of the wage negotiations, the parties agreed that they would settle wages for skilled workers before negotiating for unskilled workers. The first morning began with preliminary discussions. During the afternoon, they agreed to negotiate a two-year deal, an unusually long term for local wage agreements in Denmark, and in the evening reached preliminary agreement on wage increases for skilled workers, which were finalized next morning. After lunch, the parties settled on wage increases for unskilled workers, drawing on the shop stewards' earlier proposal for distributing wages. Later that afternoon, small adjustments were made to the overall agreement before it was concluded. 
A week after the negotiation session there was an informal meeting between the parties, where it was agreed that wage increases would be calculated as a percentage of individual wages as opposed to a percentage of the total wage sum. The next day the workers approved the agreement that was then signed by management and shop stewards.

\section{Australia: enterprise bargaining at $\mathrm{Oz}$ Manufacturing Company (Ozco)}

The first enterprise agreement was negotiated in 2003, after a two-day strike. All subsequent agreements were negotiated without recourse to industrial action, and the company was generally regarded as an example of collaborative industrial relations (Lansbury, 2014). The core of the union's negotiating team remained unchanged, principally the union official who first organized the company and a long-standing shop steward. However, the HR manager, who has extensive IR experience, including enterprise bargaining across different unionized companies, has been at Ozco only since early 2013 . He decided that the company should be represented by the production manager (who was part of the negotiation team for the previous agreement in 2011) and by the assistant HR manager, a novice to enterprise bargaining. Under Australian law, unions do not enjoy exclusive representation rights, and a number of non-union employees participated in the negotiations with encouragement from the company; although the HR manager considered their impact limited.

\section{Preparation for the negotiations}

The union's aims for the 2014 negotiations were to secure incremental improvements to the existing agreement. This was consistent with previous negotiations, where the union and the company would 'roll over' the last agreement with a schedule of new wage levels, making only minor changes to existing terms and conditions. However, management viewed the negotiations as an opportunity to address perceived strategic challenges, 'the ability to adapt and be flexible to the needs of the business', and so built its case around the issue of cost competitiveness.

Both parties recognized that negotiations would occur against the backdrop of a difficult environment for Australian manufacturing. In particular, a number of multinational corporations, such as Toyota, had recently announced the closure of their Australian operations, resulting in significant job losses.

\section{The negotiations and agreement}

From the outset it appeared that the negotiations would be difficult. When the union presented its list of claims to the company at the first formal meeting in May, management indicated that there was a significant difference in expectations. Just how different the positions were became evident when the company issued its response at the next meeting: management demanded that the new agreement should be 'cost-neutral', meaning that any wage increases must be offset by savings from changes to other conditions in the current agreement. Far from being willing to 'roll over' existing terms, the company was seeking cuts to employee conditions through the reduction or removal of entitlements such as redundancy payments and income protection insurance. Further, greater flexibility would be attained through the introduction of 'hours banking' and greater scope to use casual and fixed-term contracts.

Given the gulf between the parties' positions, two meetings through June made very little progress. Union requests for more financial information from the company were met with delay. The union also put the lack of progress down to the relatively junior status of the management team. Indeed, HR had actively discouraged the direct involvement of the owners or other senior managers, to prevent them from making unexpected changes to the company's bargaining strategy. Meanwhile, the company made presentations directly to its employees, outlining its demands and reporting aspects of recent company performance. A prominent theme was that the union's current demands threatened the financial viability of the Australian operation. Similarly, the union kept members informed about 
the state of negotiations in mass meetings.

In early July, the company held further presentations to outline six different 'agreement options' for employees to consider. Each represented a different combination of the key conditions under negotiation and was designed to meet the company's goal of a 'cost-neutral' agreement. For example, 'option 1' offered a wage increase of 3.75 percent, but removed or reduced some major existing entitlements. By contrast, 'option 2' retained these entitlements, but offered no wage increase.

With the parties effectively deadlocked, the union held meetings of members to recommend a formal ballot (as required by law) on industrial action, which was agreed. However, when the parties met again briefly the following day the management position was unchanged. The company had developed contingency plans to deal with possible industrial action, including briefing non-union employees about their right to keep working during a strike, liaising with security firms to ensure the continuity of operations, asking supervisors to refresh their manufacturing skills and further training for employees at its Thailand plant. Management responded to the prospect of industrial action by raising the stakes, informing the workforce that some of the work performed in Australia would be shifted to Thailand: the 'elephant in the room', according to the HR manager. In these meetings, held while the main delegate was on sick leave, the company advised workers that a vote in favour of industrial action in the upcoming formal ballot would result in work being sent offshore.

In the formal ballot on July 23, only about 60 percent of union members voted in favour industrial action. This relatively low level of support meant the union was unlikely to proceed with a strike or similar tactics, leaving it in a significantly weakened bargaining position. As the shop steward explained, 'the main thing was, and we explained it to them [the members], that the stronger we are the more bargaining power we've got when we go up to management. So if they see that we're weakening, well they'll come and jump on us. And that's what happened.'

The union then held mass meetings to discuss whether to take industrial action or keep negotiating. In a significant tactical and symbolic move, the company refused these meetings to be held during working hours or on company premises. With only limited support for industrial action, workers decided to continue negotiations on the basis of a reworked version of one of the company's proposed options. However, at the next negotiation meeting the company adopted a very firm position, advising the union that it would be moving offshore within six months unless its key demands were met. When the union held mass meetings to discuss its options there was little appetite to escalate the dispute through industrial action, and members decided to accept the company's basic proposal. In subsequent negotiation sessions the exact details were worked out, with the workers ultimately voting to accept the proposed agreement in late August. The workers received a 3.5 percent annual increase but lost company-funded income protection and a monthly rostered day off (although now working slightly shorter days), and the company also gained greater flexibility in the use of temporary labour. On balance, management achieved its key aims while the union made significant concessions.

\section{Comparative analysis: two different negotiation processes}

Despite notable similarities between the two case companies (e.g. industry, union density, collaborative history), the negotiations followed very different paths to reach agreement: a formal adversarial negotiation at Ozco, and a more collaborative process at DK Productions. The framework presented earlier in the paper proved sufficient for a robust comparative analysis of these different processes.

Unsurprisingly the substantive goals of the parties in each case were not aligned. The Ozco union anticipated a routine updating of the agreement in line with comparable agreements elsewhere, but management wanted significant changes. The key negotiation goal of DK management around pay differentials was also inherently conflictual, because again the union wanted to maintain the status quo. The relative scope of these agenda issues highlights a difference in the two bargaining systems: in Denmark wage issues are typically negotiated annually and separately, whereas in Australia they are 'saved up' for the episodic, comprehensive enterprise negotiations. This latter approach can make negotiations more difficult. 
Negotiation involves process as well as issues, and goal alignment also reflects the parties' expectations as to how their differences will be resolved. At DK Productions the parties gave considerable thought to preparing better than last time, by enhancing trust through informal interaction and sharing information on expectations. Additionally, the major issue in dispute (wage differentials) had been well known for some time, giving the parties opportunity to address the problem separately in anticipation of the negotiations. During these preliminary discussions and the later off-site negotiations, management shared information with shop stewards. The intensive format of the off-site negotiations both enabled and required the negotiators to engage fully with the task of finding solutions. In contrast, the negotiators at Ozco did not discuss their forthcoming negotiations in any depth. The union expected a routine updating/improvement of the agreement, but management sought to establish more unilateral control over the whole process, resulting in little interaction outside the formal negotiations which occurred through a series of meetings spread over a number of months. The negotiations followed the inherently positional format of claim and offer, centring on the existing lengthy enterprise agreement. The union initiated its negotiations by submitting a revised document; management countered with its own list of changes. This process of "working the document' invites an adversarial interaction, as it focuses on the details of clauses and invites a tradeoff mentality (Fells, 2013). Management's control also extended to the provision of information. The union had access to some public information on Ozco but the company negotiators did not readily accede to requests for more, preferring instead to communicate directly with the workforce. There was little by way of trust-building; trust extended only to presuming the general honesty of those across the table, but even that was put into question over company statements (and actions) about relocating work to Thailand.

There were two major differences in how negotiations were structured. As in previous negotiations at Ozco, the shop steward was involved but they were led by the full-time union official. In contrast, the DK Production negotiations were led on the union side by the senior shop steward, who had working relationships with management enhanced by the fact that they both worked on-site on a daily basis, whereas the Australian union official has only occasional dealings with management outside of formal bargaining. Furthermore, at DK Production each single-issue agreement would be negotiated at different times during the year in contrast to the episodic comprehensive renegotiations at Ozco. The second structural difference arose out of the representative position of the union negotiators in each case. At DK Production the union stewards were the workers' only bargaining representatives. At Ozco the presence of non-union representatives meant that the position of the union was under pressure. The presence of non-union negotiators is enabled by the legislative framework, reflecting an individualistic notion of employee democracy whereby all employees have the right to participate in negotiations.

The unions at both companies had high membership densities and so, prima facie, had significant bargaining power. In addition to union bargaining power being influenced by the presence of non-union representatives, management at Ozco was able to arrange mass meetings with workers to present its position without union presence. This 'direct dealing' potentially undermines union power in a way not observed in the Danish case (Pekarek et al., 2017).

The cases also differ in the sanctions available to workers. In Denmark, the parties cannot use industrial action during company bargaining. However, the agreement-based framework gives the parties a right of unilateral veto over all agreements at company level. This powerful lever is rarely used as it means the parties fall back on the sectoral agreement which is often less favourable to both parties.

In Australia, the parties can apply unilaterally to the FWC to terminate an expired agreement. The tribunal then applies a public interest test and considers whether termination is appropriate in all the circumstances; the outcome is thus uncertain. However, if an agreement is terminated, workers fall back on the inferior terms of the applicable 'modern award', which is why most applications are made by employers. More typically, an expired agreement is left to continue in force, normally meaning no improvements in pay or conditions for the employees but, again, potential cost savings for the employer.

In negotiation terms, both parties in Danish workplaces are faced with a less favourable default position, a characteristic of mutuality, whereas in Australia the 'termination' or 'no agreement' option is potentially more beneficial for the employer. This leaves the union in Australia 
with the strike threat option, which results in both management and union negotiators adopting an oppositional rather than collaborative strategy, each knowing the real negotiations start only after the result of the strike ballot is known. At Ozco, although there was majority support for industrial action to make management improve its offer, it was also clear that the workforce's commitment to such action was not resolute and the company could outlast the strikers. Further, the underlying strikethreat dynamic also legitimizes power-based strategies by management, such as the threat to move production offshore.

This structural and power context shapes the interpersonal dynamics, particularly the development of trust and information exchange. Frequent interaction between the shop steward and management at DK Production resulted in working relationships and trust repair that carried over into their major negotiations where the tensions might otherwise be higher. Trust led to information being exchanged and served as a foundation to the discussions. At Ozco, although the union official had a long history with the company, the lack of frequent interaction meant the union did not anticipate management's approach to the negotiations. With incomplete information at the negotiation table, the parties were left only with adversarial strategies; information was then used as a weapon, reinforcing the adversarial dynamic.

\section{Conclusion and discussion}

The trend to decentralized collective bargaining is well established in Europe. Despite a policy preference within the EU for workplace dialogue and collaboration, decentralization has taken two broadly different paths, either through state intervention resulting in increased legislative or regulatory control over both the processes and substantive outcomes of agreement-making, or through the more agreement-based framework for change typical of the Nordic countries. Australia has a long experience of the former approach and so is instructive as a comparative example of possible future directions for European systems taking a similar path.

From our two cases, DK Production exemplifies mutually reinforcing interactions between management and shop steward in an external framework of agreement-making that gives them no real option but to interact and collaborate. In contrast, the context for negotiations at Ozco did not encourage informal interaction but directed the negotiators towards episodic arms-length negotiation and further, despite the stated intention to promote collaboration, resulted in those negotiations being adversarial. The Australian legal framework prescribes a number of activities that formalize the negotiation process and do not encourage the development of trust or informal problem-solving interactions between the negotiators. The agreement-based framework for company bargaining in Denmark allowed the local bargaining parties to focus attention inwards on their own bargaining process, whereas the legalistic framework in Australia required the local bargaining parties to evaluate constantly their process against the external formal requirements. Referring again to Table 2 , the Danish case displays the characteristics of stability whereas the Australian case shows signs of fragility.

Both cases, and the Australian case in particular, show the importance of management strategy (Walton et al, 1994). The capacity for workers to veto decentralized agreements and revert back to the Industriens Overenskomst in Denmark would appear to provide a safeguard against managerial attempts at a 'forcing' strategy. By contrast, aspects of Australia's bargaining framework (such as the scope for non-union representatives and elaborate procedural requirements around industrial action) would appear to strengthen management's capacity to influence employee sentiment in line with corporate interests and to leverage bargaining power in negotiations.

Our analysis, informed by the findings of the negotiation literature, highlights the complexity and dynamics of workplace bargaining and so contributes to the development of the broader (and management-oriented) strategic analysis of Walton et al. (1994), and adds to the research on mutual gains and partnership. The process-tracing methodology helped us gauge the impact of different forms of decentralization on the dynamics and durability of the bargaining relationships, to complement research on developments in the broader institutional frameworks governing industrial relations.

Our empirical findings feed into European debates on how to facilitate mutual-gains bargaining in times of decentralization and deregulation. The role of legislation in the decentralization process in 
Australia seems to leave local managers and shop stewards with more fragile conditions for reproducing partnership relations than in Denmark, where the industry collective agreements in the decentralization process seem to offer more stable conditions for the reproduction of local partnerships. Visser (2016) has described the Danish approach as an example of articulated decentralization, in recognition of strong bargaining at both industry and local levels, with controlled flexibility between the levels. However, from another perspective, the key point of the Danish and other similar systems is that the parties themselves articulate the framework within which local negotiations occur. In contrast, the legislative approach to decentralization is articulated by a third party, the state. As our research shows, this legislative approach to workplace bargaining can undermine the very dynamics of the process, and with it the reproduction of collaborative relationships between management and union. This suggests that unions looking to address the many long-standing but increasing challenges to their legitimacy and influence (Hyman, 2015; Kelly, 1998) should focus their efforts on rebuilding their negotiating power at the workplace over and above pursuing legislative reform in the political arena.

\section{Acknowledgements}

We are grateful to our colleagues Trine P. Larsen and Christian Lyhne Ibsen for valuable comments on earlier versions of this article. Earlier versions have also been presented to a number of colleagues at The 17th ILERA World Congress, Cape Town, South Africa, September 7-11, 2015 and The 28th SASE Conference, Berkeley, USA, June 24-26, 2016. The authors would like to thank the audiences for their fruitful comments that have helped improve the manuscript. Many thanks also to the anonymous referees and the Editor.

\section{Funding}

This research received no specific grant from any funding agency in the public, commercial, or not-for-profit sectors.

\section{References}

Andersen SK, Dølvik, JE and Ibsen, CL (2014) Nordic labour market models in open markets. Brussels: ETUI Report 132.

Amlinger, M, Bispinck, R and Schulten, T (2016) The German minimum wage: Experiences and perspectives after one year. Düsseldorf: WSI.

ABS (Australian Bureau of Statistics) (2015a) Employee Earnings and Hours, Australia. Canberra: ABS.

ABS (2015b) Characteristics of employment, Australia. Canberra: ABS.

ABS (2015c) Australian National Accounts. Canberra: ABS.

Baccaro, L and Howell, C (2011) A common neoliberal trajectory: The transformation of industrial relations in advanced capitalism. Politics and Society 39(4):521-563.

Bacon N and Blyton P (2007) Conflict for mutual gains. Journal of Management Studies 44(5):814834.

Bazerman MH and Neale MA (1992) Negotiating Rationally. New York: Free Press.

Beach D and Pedersen RB (2013) Process-Tracing Methods. Ann Arbor: University of Michigan Press.

Bechter, B and Brandl, B (2015): 'Developments in European industrial relations' in European Commission, Industrial Relations in Europe 2014. Luxembourg: Publications Office, pp. 1740.

Campos Lima, MP and Jørgensen, CJ (2016) Trajectories of collective bargaining in Denmark and Portugal: from national determined 'organized Industrial Relations' to supra-national determined 'disorganized Industrial Relations'? In TP Larsen and A Ilsøe (eds) Den danske model set udefra. Copenhagen: DJØF Publishing, pp. 223-250.

Chamberlain, NW and Kuhn, JW (1965) Collective Bargaining. New York: McGraw-Hill.s:

Collier D (2011) Understanding Process Tracing. Political Science and Politics 44(4): 823-830.

Cutcher-Gershenfeld J (2011) Bargaining when the future of an industry is at stake: Lessons from 
UAW-Ford collective bargaining negotiations. Negotiation Journal 27(2):115-145. s:

Danmarks Statistik (2013) Industriens udvikling 2000-2012. Copenhagen: Danmarks Statistik.

De Dreu, CKW, Weingart, LR and Kwon, S (2000) Influence of social motives on integrative negotiation: a meta-analytic review and test of two theories. Journal of Personality and Social Psychology 78(5):889-905.ss:

Due, J, Madsen, JS and Pihl, M (2010) Udviklingen i den faglige organisering: Årsager og konsekvenser for den danske model. LO-Dokumentation 1. Copenhagen: LO.

Due J, Madsen JS, Jensen CS and Petersen LK (1994) The Survival of the Danish Model. A Historical Sociological Analysis of the Danish System of Collective Bargaining. Copenhagen: DJØF.

Dølvik JE (2016) The Danes' uneasy relationship between collective bargaining and legislation in implementing EU workers' rights: The case of minimum wage setting. In TP Larsen and A Ilsøe (eds) Den danske model set udefra. Copenhagen: DJØF Publishing, pp.103-126.

European Commission (2015) Industrial Relations in Europe. Luxembourg: Publications Office of the European Union.

Fells RE (2013) Negotiation success: An application of the Halpert et al. Path Model. Negotiation and Conflict Management Research 6(2):133-150.

Fells RE and Prowse P (2016) Negotiations in the workplace: overcoming the problem of asymmetry. In Elgoibar P, Euwema M. and Munduate L (eds) Building trust and constructive conflict management in organizations. Dordrecht: Springer International, pp.75-92.

Gahan P and Pekarek A. (2012) The rise and rise of enterprise bargaining in Australia, 1991-2011. Labour and Industry 22(3):195-222.

George AL and Bennett, A (2005) Case Studies and Theory Development in the Social Sciences. Cambridge: MIT Press.

Hamilton R (2011) Waltzing Matilda and the Sunshine Harvester Factory: The Early history of the Arbitration Court, the Australian Minimum Wage, Working Hours and Paid Leave. Melbourne: Fair Work Australia.

Hyman R (2015) Three Scenarios for Industrial Relations in Europe. International Labour Review, 154(1):5-14.

Ilsøe A (2012) The flip side of organized decentralization: Company-level bargaining in Denmark. British Journal of Industrial Relations, 50(4):760-781.

Ilsøe A (2009) Strejkefri. Historisk fald i antallet af konflikter. Politiken, September 24th.

Katz HC (1993) The decentralization of collective bargaining: A literature review and comparative analysis. Industrial and Labor Relations Review 47(1):3-22.

Kelly J (1998) Rethinking Industrial Relations: Mobilisation, Collectivism and Long Waves. London: Routledge.

Kelly J (2004) Social partnership agreements in Britain: labor cooperation and compliance', Industrial Relations. 43(1):267-292.

Keune, M (2015) Shaping the future of industrial relations in the EU: Ideas, paradoxes and drivers of change. International Labour Review, 154 (1):47-66.

Lansbury R (2014) An elusive quest: Effective communications and employee engagement in Australia, Fair Work Commission, Melbourne.

Lewicki RJ and Stevenson MA (1997) Trust development in negotiation: proposed actions and a research agenda. Business and Professional Ethics Journal. 16:99-133.

Marginson P (2015) Coordinated bargaining in Europe: From incremental corrosion to frontal assault? European Journal of Industrial Relations, 21(2):97-114.

Navrbjerg SE, Nordestgaard M and Due J (2001) Fremtidens overenskomster i decentraliseringens tegn. Copenhagen: CO-industri.

Oxenbridge S and Brown W (2004) Achieving a new equilibrium? The stability of cooperative employer-union relationships. Industrial Relations Journal. 35(5):388-402.

Pekarek, A, Landau, I, Gahan, P, Forsyth, A and Howe, J (2017) Old game, new rules? The dynamics of enterprise bargaining under the Fair Work Act. Journal of Industrial Relations 59(1): 44-64.

Schulten T (2005) Changes in National Collective Bargaining Systems since 1990: The German Case. Dublin: Eurofound.

Schulten T (2016) Danish, German and European Perspectives on (Statutory) Minimum Wages. In TP 
Larsen and Ilsøe A (eds) Den danske model set udefra. Copenhagen: DJØF Publishing. Tansey O (2007) Process tracing and elite interviewing: A case for non-probability sampling. Political Science and Politics 40(4):765-772.

Traxler F (1995) Farewell to labour market associations? Organized versus disorganized decentralization as a map for industrial relations'. In C Crouch and Traxler F (eds) Organized Industrial Relations in Europe: What Future? Aldershot: Avebury, pp.3-19.

Thompson L (1991) Information exchange in negotiation. Journal of Experimental and Social Psychology 27:161-179.

Thornthwaite L and Sheldon P (1996) The Metal Trades Industry Association, bargaining structures and the Accord. Journal of Industrial Relations. 38(2):171-195.

Visser J (2016) Variation in decentralization: articulation and legal culture. In TP Larsen and Ilsøe A (eds) Den danske model set udefra. Copenhagen: DJØF Publishing, pp.53-102.

Voss, E, Schöneberg, K and Rodriguez Contreras, R (2015) Collective bargaining in Europe in the 21 st century. Luxembourg: Publications Office.

Walton RE, Cutcher-Gershenfeld J and McKersie RB (1994) Strategic Negotiations. Boston: Harvard Business School Press.

Walton RE and McKersie RB (1965) A Behavioral Theory of Labor Negotiations. New York: McGraw Hill.

\section{Author biographies}

Anna Ilsøe is Associate Professor in the Employment Relations Research Centre, University of Copenhagen, Denmark

Andreas Pekarek is a lecturer in the Department of Management and Marketing, The University of Melbourne, Australia

Ray Fells is Professor in the Business School, University of Western Australia 


\section{Table 1. Frameworks for management-union negotiations}

\begin{tabular}{|c|c|}
\hline \multirow{3}{*}{$\begin{array}{l}\text { Core } \\
\text { characteristics } \\
\text { Sectoral } \\
\text { agreement }\end{array}$} & Denmark \\
\hline & $\begin{array}{l}\text { Voluntaristic management-union } \\
\text { framework }\end{array}$ \\
\hline & $\begin{array}{l}\text { Industriens Overenskomst, negotiated } \\
\text { every two to four years. Four chapters } \\
\text { can be replaced by local agreements }\end{array}$ \\
\hline $\begin{array}{l}\text { Company } \\
\text { agreements }\end{array}$ & $\begin{array}{l}\text { Single-issue agreements on pay, hours, } \\
\text { training etc. Pay is negotiated annually, } \\
\text { No industry-level ratification, either } \\
\text { open-ended or fixed term }\end{array}$ \\
\hline $\begin{array}{l}\text { Negotiators at } \\
\text { company level }\end{array}$ & $\begin{array}{l}\text { Management and shop stewards; } \\
\text { agreement-based protection for } \\
\text { employees engaged in union activities }\end{array}$ \\
\hline $\begin{array}{l}\text { Industrial } \\
\text { action }\end{array}$ & $\begin{array}{l}\text { No provision for legal industrial action } \\
\text { on company agreements }\end{array}$ \\
\hline $\begin{array}{l}\text { Ending an } \\
\text { agreement }\end{array}$ & $\begin{array}{l}\text { Either party can revert to the terms of } \\
\text { the Industriens Overenskomst with two } \\
\text { months' notice }\end{array}$ \\
\hline
\end{tabular}

Australia

Legalistic tripartite management-uniontribunal framework

Sectoral 'modern award', periodically reviewed and determined by the tribunal

Enterprise agreement covering all employment conditions, replacing the Industry Award but must be better overall. Duration typically 4 years Management, often aided by employers' association, and external union official supported by shop stewards; legislative protection for employee representatives Tightly prescribed process to be followed before any industrial action Either party can apply to have an expired agreement terminated, in which case terms revert to Industry Award 


\section{Table 2. Fragility and stability in negotiation settings}

Characteristics of stability

Some congruent goals

mutual gains seen as possible

Formal and informal

Negotiators with bargaining authority

Power may shape expectations, but not exercised during

negotiation

Frequent formal and informal

interaction

Some identification-based trust

Open
Dimensions of negotiation

Goal alignment

Negotiation structures

Power distribution

Interpersonal dynamics: trust

Interpersonal dynamics:

information exchange
Characteristics of fragility

Incompatible goals

Outcomes seen as zero-sum

Formal

Negotiators as delegates

Strategies based on the (implied or actual) use of power

Infrequent and formal interactions

Calculus-based trust

Limited

Used strategically 